\title{
Effects of different polishing techniques on the surface roughness of dental porcelains
}

\author{
Ișil SARIKAYA', Ahmet Umut GÜLER ${ }^{2}$
}

1- DDS, PhD, Research Assistant, Department of Prosthodontics, Faculty of Dentistry, Ondokuz Mayis University, Samsun, Turkey.

2- DDS, PhD, Associate Professor, Department of Prosthodontics, Faculty of Dentistry, Ondokuz Mayis University, Samsun, Turkey.

Corresponding address: Dr. Isil SARIKAYA - Ondokuz Mayis Üniversitesi - Dis Hekimligi Fakültesi - Protetik Dis Tedavisi Anabilim Dali - Kurupelit - SAMSUN, TÜRKEY - Fax: +90-362-457-6032. E-mail: sarikaya.i@ hotmail.com

Received: November 04, 2008 - Modification: July 08, 2009 - Accepted: August 11, 2009

\section{ABSTRACT}

\begin{abstract}
Ojective: The purpose of this study was to evaluate the effects of different polishing techniques on the surface roughness of dental porcelains. Material and Methods: Fifty-five cylindirical specimens $(15 \times 2 \mathrm{~mm}$ ) were prepared for each feldspathic (Vita VMK 95, Ceramco III) and low-fusing dental porcelain (Matchmaker). Fifty-five specimens of machinable

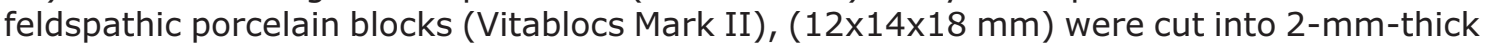
slices $(12 \times 14 \mathrm{~mm})$ with low speed saw. The prepared specimens were divided into 11 groups $(n=5)$ representing different polishing techniques including control $((C)$ no surface treatment), glaze (G) and other 9 groups that were finished and polished with polishing discs (Sof-Lex) (SI), two porcelain polishing kits (NTI (Pk), Dialite II (Di)), a diamond polishing paste (Sparkle) (Sp), a zirconium silicate based cleaning and polishing prophy paste (Zircate) ( $\mathrm{Zr}$ ), an aluminum oxide polishing paste (Prisma Gloss) ( $\mathrm{Pg}$ ), and combinations of them. The surface roughness of all groups was measured with a profilometer. The data were analyzed with a 2-way analysis of variance, and the mean values were compared by the Tukey Honestly Significant Difference test $(\alpha=0.05)$. Results: For all porcelain material groups, the lowest Ra values were observed in Group Gl, Group SI, Group Pk, and Group $\mathrm{Di}$, which were not significantly different from each other $(p>0.05)$. When comparing the 4 different porcelain materials, the machinable feldspathic porcelain block group (Mark II) demonstrated statistically significantly less Ra values than the other porcelain materials tested $(p<0.05)$. No significant difference was observed between the VMK 95 and Ceramco III porcelain groups $(p=0.919)$, also these groups demonstrated the highest Ra values. Conclusion. Subjected to surface roughness, the surfaces obtained with polishing and/or cleaning-prophy paste materials used alone were rougher compared to the surfaces finished using Sof-lex, Dialite, and NTI polishing kit. Polishing kits and discs were found more effective than the polishing pastes used alone or combined use with Sof-lex discs, thus improving surface smoothness.
\end{abstract}

Key words: Dental porcelain. Polishing techniques. Surface roughness.

\section{INTRODUCTION}

In addition to the improved esthetic properties, such as translucency, color and intensity, the main advantages of dental porcelain materials are excellent biocompatibility and durability ${ }^{3}$.

Although occlusal adjustment of porcelain restorations may be necessary for correction of inadequate contours or improved esthetics, roughened ceramic surface creating with this procedure, which may cause an increased rate of plaque accumulation, gingival inflammation and adverse soft tissue reaction ${ }^{1,10,20,24}$. In addition porcelain reduction with grinding may also cause decrease the strength of the ceramic restoration ${ }^{4,12,14}$.

Since the final occlusal adjustments of a ceramic restoration has to be made after cementation, there is always need for a careful 
intraoral polishing of the surfaces. Exposed porcelain surfaces should be smoothed to prevent excessive wear of the opposing dentition and to minimize plaque retention ${ }^{18}$. Highly polished porcelain surfaces have strength values comparable to those of specimens that were polished and glazed ${ }^{3}$. However, chairside porcelain polishing is efficient and easy for the clinician. Intraoral polishing also provides infection control by eliminating repeated laboratory procedures.

Surface roughness (Ra) refers to the finer irregularities of the surface texture that usually result from the action of the production process or material condition and is measured in micrometers $(\mu \mathrm{m})^{16}$. Generally, a smooth surface is desirable to reduce retention of bacteria and to have a shiny appearance ${ }^{7}$. Various studies are available to support using different polishing techniques on porcelain surface instead of glazing $2,11,17,18,24$.

The purpose of this study was to evaluate the effects of different polishing techniques on the surface roughness of different dental porcelains. The hypothesis for this study was that the different polishing techniques would have different effects on the surface roughness of dental porcelains.

\section{MATERIAL AND METHODS}

In the present study, four commonly used and commercially available dental porcelains and different polishing systems were investigated in this study (Figure 1 ). Fifty-five cylindrical specimens $(15 \times 2 \mathrm{~mm})$ were prepared for each of feldspathic and low-fusing dental porcelains by one investigator who condensed the porcelains into a polyvinylsiloxane mold in a standardized manner ${ }^{6}$. After each specimen was mixed using the same amount of porcelain and liquid, placed into the mold and compressed with a plastic plunger. The excess moisture was absorbed by using a tissue (Selpak; Eczaclbasl Group, Kocaeli, Turkey). After removal from the mold, the specimens were fired in one furnace (Programat P80; Ivoclar-Vivadent, Liechtenstein) according to the manufacturer's directions (approximately 920-960 ${ }^{\circ} \mathrm{C}$ ).

Fifty-five specimens of machinable ceramic blocks $(12 \times 14 \times 18 \mathrm{~mm})$ were cut into 2 -mm-thick slices (2x14 mm) with a low-speed saw (Isomet Low Speed Saw, Buehler, Lake Bluff, IL, USA). All ceramic discs were wet-ground with 600-grit silicon carbide paper during $10 \mathrm{~s}$ on a $300-r p m$ grinding machine (Buehler Metaserv, Buehler, Germany).

The prepared specimens were randomly divided into 11 groups of 5 specimens each according to the polishing techniques. The polishing procedure was done by a single investigator and different polishing groups are listed in Figure 2. Group C - specimens served as the control group with no polishing procedure applied. Group GI - specimens were glazed using the specific glaze medium for each case. Group

\begin{tabular}{|c|c|c|}
\hline Material Type & Product & Manufacturer \\
\hline Feldspathic porcelain & VMK 95 & Vita Zahnfabrik, Germany \\
Feldspathic porcelain & Ceramco III & Degudent GmbH, USA \\
Low-fusing porcelain & Matchmaker MC & Schottlander, UK \\
Feldspathic porcelain blocks & Vitablocs Mark II & Vita Zahnfabrik, Germany \\
Finishing and polishing disc & Sof- Lex & 3M ESPE, USA \\
Porcelain polishing kit & NTI CeraGlaze & NTI- Kahla GmbH, Germany \\
Porcelain polishing kit & Dialite II & Brasseler, USA \\
Diamond polishing paste & Sparkle & Pulpdent, USA \\
Zirconium silicate cleaning- polishing prophy & Zircate & Dentsply Int. Inc., USA \\
pluminum oxide polishing paste & & Dentsply Int. Inc., USA \\
\hline
\end{tabular}

Figure 1- Materials used in this study 
SI - specimens were polished with a series of 12.7-mm-diameter polishing discs (Sof-Lex; 3M/ ESPE, St. Paul, MN, USA) mounted on an electric handpiece set at a speed of $10,000 \mathrm{rpm}$ during $10 \mathrm{~s}$ for coarse and medium discs, and 30,000 rpm during $10 \mathrm{~s}$ for fine and superfine discs, according to the manufacturer's instructions. Group Pk - specimens were polished with NTI Cera Glaze polishing kit on an electric handpiece at $15,000 \mathrm{rpm}$ for $10 \mathrm{~s}$ with pre-polishing wheel, at $10,000 \mathrm{rpm}$ during $10 \mathrm{~s}$ with refined finishing wheel and at 5,000 rpm for $10 \mathrm{~s}$ with high-shine polishing wheel according to the manufacturer's instructions. Group Di - specimens were polished with Dialite II porcelain polishing kit including pre, fine and high-shine wheels on an electric handpiece at $10,000 \mathrm{rpm}$ for $10 \mathrm{~s}$ following the manufacturer's instructions. Groups Sp, Zr and Pg - Sparkle diamond polishing paste, Zircate zirconium silicate cleaning-prophy paste and Prisma Gloss aluminum oxide polishing paste, respectively, were applied for $10 \mathrm{~s}$ to the specimens with a prophylaxis rubber cup (Kenda Polishers, Kenda AG, Liechtenstein) mounted on an electric handpiece at 15,000 rpm. Group specimens were applied with a prophylaxis rubber cup on an electric handpiece at 15,000 rpm for 10 s. Group SISp - specimens were polished as in Group SI and diamond polishing paste was applied as described for Group Sp. Group SIZr specimens were polished as in Group SI and zirconium silicate cleaning-prophy paste was applied as described for Group Zr. Group SIPg specimens were polished as in Group SI and aluminum oxide polishing paste was applied as described for Group Pg. The specimens were then ultrasonically cleaned (Eurosonic Energy, Euronda, Italy) with deionized water for $10 \mathrm{~min}$ and dried.

The specimens were stabilized with silicone impression material into a brass mold and three roughness measurements $(R a, \mu \mathrm{m})$ were performed on each sample using a profilometer (Perthometer M2, Mahr GmbH, Germany). A cutoff value of $0.25 \mathrm{~mm}$ allowed detecting those irregularities $^{8,22}$. A diamond stylus (NHT-6) of 2 $\mu \mathrm{m}$ radius and $90^{\circ}$ stylus angle was traversed at a constant speed across each of the finished

\begin{tabular}{|c|c|}
\hline Group & Polishing techniques \\
\hline Group- C & Control (no surface treatment) \\
Group- Gl & Glaze \\
Group- SI & Sof- Lex \\
Group- Pk & NTI CeraGlaze Polishing kit \\
Group- Di & Dialite II \\
Group- Sp & Sparkle \\
Group- Zr & Zircate \\
Group- Pg & Prisma Gloss \\
Group- SISp & Sof- Lex+ Sparkle \\
Group- SIZr & Sof- Lex+ Zircate \\
Group- SIPg & Sof- Lex+ Prisma Gloss \\
\hline
\end{tabular}

Figure 2- Polishing methods

samples of ceramic sample with a force of $0.7 \mathrm{~N}$. Before measurements of each group, the profilometer was calibrated. All profilometer records were made as close as possible to the sample center ${ }^{8}$. For each specimen, 3 measurements were made and the mean was calculated to obtain the general surface characteristics of the specimens. The Ra value describes the mean value for a surface that has been traced by the profilometer ${ }^{8,20}$. A lower Ra value indicates a smoother surface.

The effect of porcelain type and polishing procedure as well as their interactions on the surface roughness was evaluated by two-way ANOVA tests using SPSS for Windows statistical software version (12.0.1; SPSS Inc, Chicago, IL, USA). The mean values were than compared by the Tukey honestly significant difference test $(\alpha=0.05)$.

\section{RESULTS}

According to the two-way ANOVA results, porcelain materials, polishing techniques, and their interaction were statistically significant $(p<0.05)$ (Table 1$)$. Mean surface roughness values (and standard deviation) and group differences $(\mathrm{Ra})$ of the feldspathic porcelain materials (Vita VMK 95, Ceramco III), low-fusing porcelain material (Matchmaker MC), and machinable feldspathic porcelain block (Vitablocs Mark II) are listed in Tables 2, 3, 4 and 5, respectively. 
Table 1- Two-way ANOVA for porcelain materials and different polishing techniques

\begin{tabular}{lrcrrr}
\hline Variable (source) & $\boldsymbol{d f}$ & Sum of squares & Mean squares & F & P \\
\hline Polishing technique & 10 & 25.328 & 2.533 & 35.107 & $.000^{*}$ \\
Porcelain & 3 & 31.779 & 10.593 & 146.830 & $.000^{*}$ \\
Interaction & 30 & 17.431 & .581 & 8.054 & $.000^{\star}$ \\
Error & 176 & 12.698 & .072 & & \\
\hline
\end{tabular}

${ }^{*}$ Significant difference at $p<.05$.

Table 2- Mean (SD) of surface roughness and differences between groups for Vita VMK 95 porcelain

\begin{tabular}{lll}
\hline Group & Ra & Difference* \\
\hline $\mathrm{C}$ & $1.134(0.64)$ & $\mathrm{a}, \mathrm{b}$ \\
$\mathrm{Gl}$ & $0.724(0.19)$ & $\mathrm{a}$ \\
$\mathrm{SI}$ & $0.729(0.17)$ & $\mathrm{a}$ \\
$\mathrm{Pk}$ & $0.640(0.15)$ & $\mathrm{a}$ \\
$\mathrm{Di}$ & $0.700(0.23)$ & $\mathrm{a}$ \\
$\mathrm{Sp}$ & $1.639(0.26)$ & $\mathrm{b}, \mathrm{c}$ \\
$\mathrm{Zr}$ & $2.241(0.41)$ & $\mathrm{c}$ \\
$\mathrm{Pg}$ & $1.728(0.47)$ & $\mathrm{b}, \mathrm{c}$ \\
$\mathrm{SISp}$ & $1.929(0.76)$ & $\mathrm{b}, \mathrm{c}$ \\
$\mathrm{SIZr}$ & $1.731(0.48)$ & $\mathrm{b}, \mathrm{c}$ \\
$\mathrm{SIPg}$ & $1.122(0.24)$ & $\mathrm{a}, \mathrm{b}$ \\
\hline
\end{tabular}

*Different letters indicate statistically significant difference between the groups $(p<0.05)$.

Table 4- Mean (SD) of surface roughness and differences between groups for Matchmaker MC porcelain

\begin{tabular}{lll}
\hline Group & Ra & Difference* $^{*}$ \\
\hline $\mathrm{C}$ & $1.015(0.23)$ & $\mathrm{b}, \mathrm{c}, \mathrm{d}$ \\
$\mathrm{Gl}$ & $0.456(0.11)$ & $\mathrm{a}$ \\
$\mathrm{SI}$ & $0.757(0.11)$ & $\mathrm{a}, \mathrm{b}, \mathrm{c}$ \\
$\mathrm{Pk}$ & $0.691(0.16)$ & $\mathrm{a}, \mathrm{b}$ \\
$\mathrm{Di}$ & $0.366(0.08)$ & $\mathrm{a}$ \\
$\mathrm{Sp}$ & $0.746(0.26$ & $\mathrm{a}, \mathrm{b}, \mathrm{c}$ \\
$\mathrm{Zr}$ & $1.728(0.20)$ & $\mathrm{f}$ \\
$\mathrm{Pg}$ & $1.700(0.10)$ & $\mathrm{f}$ \\
$\mathrm{SISp}$ & $1.262(0.32)$ & $\mathrm{d}, \mathrm{e}, \mathrm{f}$ \\
$\mathrm{SIZr}$ & $1.652(0.17)$ & $\mathrm{e}, \mathrm{f}$ \\
$\mathrm{SIPg}$ & $1.175(0.41)$ & $\mathrm{c}, \mathrm{d}, \mathrm{e}$ \\
\hline
\end{tabular}

*Different letters indicate statistically significant difference between the groups $(p<0.05)$.
Table 3- Mean (SD) of surface roughness and differences between groups for Ceramco III porcelain

\begin{tabular}{lll}
\hline Group & Ra & Difference* \\
\hline $\mathrm{C}$ & $1.667(0.21)$ & $\mathrm{c}, \mathrm{d}$ \\
$\mathrm{GI}$ & $0.609(0.23)$ & $\mathrm{a}$ \\
$\mathrm{SI}$ & $0.617(0.10)$ & $\mathrm{a}$ \\
$\mathrm{Pk}$ & $0.639(0.10)$ & $\mathrm{a}$ \\
$\mathrm{Di}$ & $0.999(0.26)$ & $\mathrm{a}, \mathrm{b}$ \\
$\mathrm{Sp}$ & $1.824(0.39)$ & $\mathrm{c}, \mathrm{d}$ \\
$\mathrm{Zr}$ & $1.974(0.12)$ & $\mathrm{d}$ \\
$\mathrm{Pg}$ & $1.872(0.18)$ & $\mathrm{c}, \mathrm{d}$ \\
$\mathrm{SISp}$ & $1.400(0.19)$ & $\mathrm{b}, \mathrm{c}$ \\
$\mathrm{SIZr}$ & $1.481(0.22)$ & $\mathrm{b}, \mathrm{c}$ \\
$\mathrm{SIPg}$ & $1.595(0.29)$ & $\mathrm{c}, \mathrm{d}$ \\
\hline
\end{tabular}

*Different letters indicate statistically significant difference between the groups $(p<0.05)$.

Table 5- Mean (SD) of surface roughness and differences between groups for Mark II porcelain

\begin{tabular}{lll}
\hline Group & Ra & Difference* $^{*}$ \\
\hline C & $0.314(0.12)$ & a \\
GI & $0.406(0.18)$ & a, b \\
SI & $0.431(0.09)$ & a, b \\
Pk & $0.584(0.04)$ & b \\
Di & $0.434(0.04)$ & $a, b$ \\
Sp & $0.380(0.12)$ & $a, b$ \\
Zr & $0.312(0.11)$ & $a$ \\
Pg & $0.342(0.07)$ & $a$ \\
SISp & $0.386(0.06)$ & a, b \\
SIZr & $0.321(0.12)$ & a \\
SIPg & $0.364(0.13)$ & a, b \\
\hline
\end{tabular}

*Different letters indicate statistically significant difference between the groups $(p<0.05)$. 
For the VMK 95 feldspathic porcelain material, the lowest Ra values were observed in Group $\mathrm{Gl}$ (0.724), Group SI (0.729), Group Pk (0.640), Group Di (0.700), Group C (1.134) and Group SIPg (1.122), which were not significantly different from each other $(p=0.732)$. The highest Ra value in the VMK 95 porcelain material was observed in Group Zr (2.241), which were not significantly different from Group Sp (1.639), Group Pg (1.728), Group SISp (1.929) and Group $\operatorname{SIZr}(1.731)(p=0.466)$. The differences between VMK 95 feldspathic porcelain material group are listed in Table 2. For the Ceramco III feldspathic porcelain material, the lowest $\mathrm{Ra}$ values were observed in Group GI (0.609), Group SI (0.617), Group Pk (0.639) and Group Di (0.999), which were not significantly different from each other $(p=0.230)$. The highest $R a$ value in the Ceramco III feldspathic porcelain material was observed in Group $\operatorname{Zr}$ (1.974) which were not significantly different from Group C (1.667), Group Sp (1.824), Group Pg (1.872) and Group SIPg (1.595) $(p=0.265)$ (Table 3).

For the low-fusing porcelain material, the lowest $\mathrm{Ra}$ values were observed in Group $\mathrm{Di}$ (0.366), which were not significantly different from Group GI (0.456), Group SI (0.757), Group Pk (0.691) and Group Sp (0.746) $(p=0.203)$. No significant difference was observed among Group SIZr (1.652), Group SIPg (1.175), Group SISp (1.262), Group Pg (1.700) and Group Zr (1.728), also these groups demonstrated the highest $\mathrm{Ra}$ values for the low-fusing porcelain material tested $(p=0.063)$ (Table 4).

For the machinable feldspathic porcelain block, the lowest Ra values were observed in Group C (0.314), Group GI (0.406), Group SI (0.431), Group Di (0.434), Group Sp (0.380), Group Zr (0.312), Group Pg (0.342), Group SISp (0.386), Group SIZr (0.321) and Group SIPg (0.364), which were not significantly different from each other $(p=0.816)$. Group Pk $(0.584)$ differed significantly from these groups $(p<0.05)$. No significant difference was observed among Group Pk (0.584), Group GI (0.406), Group SI (0.431), Group Di (0.434), Group Sp (0.380), Group SISp (0.386) and Group SIPg (0.364) $(p=0.100)$ (Table $5)$.
When comparing the 4 different porcelain materials, the machinable feldspathic porcelain block (Mark II) demonstrated significantly lower $\mathrm{Ra}$ values than the other porcelain materials tested $(p<0.05)$. No significant difference was observed between the VMK 95 and Ceramco III porcelains $(p=0.919)$, which presented the highest Ra values.

\section{DISCUSSION}

The hypothesis set as the premise of this study was accepted, since different polishing techniques affected the surface roughness of the evaluated dental porcelains. In the present study the efficiency of different porcelain polishing kits, polishing discs, cleaning-prophy paste materials and their combinations were compared. These materials were selected among frequently used dental porcelain systems as being fast and effective on creating smoothed porcelain surfaces.

The Ra parameter obtained with a profilometer is used to describe the surface texture of the porcelain specimens. This parameter describes the overall roughness of a surface and can be defined as the arithmetical average value of all absolute distances of the roughness profile from the center line within the measuring length ${ }^{23}$.

Various finishing and polishing techniques can use on porcelain surface to preserve its structural resistance and obtain a clinically acceptable smoothness comparing with glazing ${ }^{1,2,11,17,18,24}$. Previous studies on surface roughness of dental porcelains demonstrated that very smooth surfaces were obtained when restorations were polished with rubber wheel, Sof-lex discs, porcelain polishing kit, diamond paste and aluminum oxide paste ${ }^{1,5,17-19,21,24}$. In this study, it was observed that using porcelain polishing disc or polishing kits, diamond pastes or alumina pastes alone created surfaces as smooth as glazed specimens as similar studies. This result indicates that polishing kits and disc systems had a similar effect on ceramic surface roughness compared to glazing.

According to Al Wahadni, et al. ${ }^{1}$ (1998), polishing of a ceramic restoration by diamond 
paste at the final stage after clinical adjustment was equivalent to reglazing. Hulterstrom, et al. ${ }^{9}$ (1993) found that Sof-lex system produced the best results for Mark I porcelain when no polishing paste was used. In the present study, the Soflex system produced the lowest Ra values for all porcelains. Final polishing with a diamondcontaining polishing paste after polishing with the Sof-lex system produced no significant decrease in the Ra value for Mark II ceramics. Hulterstrom, et $\mathrm{al}^{9}$ (1993) recommended that final polishing with the fairly expensive diamond paste did not significantly improve the smoothness of the ceramic surface polished with the Sof-lex system. Furthermore several studies have shown that final polishing with a diamond paste did not improve the surface smoothness of ceramic restorations ${ }^{8,9,12}$.

Due to the difficult in reaching intraoral access, occlusal corrections may result in insufficient polishing and the formed microcracks may be susceptible to later catastrophic fractures. Therefore, much care must be taken in order to make a careful polishing of inlay areas that had been previously subjected to rotary occlusal corrections to prevent from this particular problem $^{13}$.

In the present study, the surfaces obtained with polishing and/or cleaning-prophy paste materials were rougher when used alone compared with the surfaces finished through using Sof-lex, Dialite, and NTI polishing kit. This finding is in agreement with previous reports investigating the effects of different polishing systems on the surface roughness of ceramics $^{8,9,15,19}$.

According to the results of present study, the machinable feldspathic porcelain block group (Mark II) demonstrated significantly lower Ra values than the other porcelain materials. No significant difference was observed between the VMK 95 and Ceramco III porcelains, which presented the highest Ra values. Several studies on finishing and polishing of dental ceramics have been published, but there is a lack of studies investigating the effectiveness of different polishing techniques for the newer types of dental porcelain, such as Mark II porcelain blocks. There were not significant differences among the various polishing techniques for Mark II porcelains, and this is thought to be due to the extreme hardness of Mark II feldspathic blocs.

The present study has some limitations. Although intraoral polishing systems have been used, this is an in vitro study and so the efficiency of polishing systems might be different under clinical conditions. Furthermore, different results might be expected with different types of porcelain and polishing protocols. Further investigations are necessary to evaluate the surface roughness of other porcelain systems after polishing with different polishing protocols.

\section{CONCLUSION}

Within the limitation of this study, glazing and polishing discs and kits have shown lower $\mathrm{Ra}$ values than those obtained using polishing pastes. Polishing kits and discs were found more effective than the polishing pastes used alone or combined with Sof-lex discs, resulting in improved surface smoothness. If occlusal adjustment of a ceramic restoration has to be made after cementation there is always need for a careful intraoral polishing with polishing kits and discs.

\section{REFERENCES}

1- Al Wahadni A, Martin DM. Glazing and finishing dental porcelain: a literature review. J Can Dent Assoc 1998;64(8):580-3.

2- Ancowitz S, Torres T, Rostami H. Texturing and polishing: The final attempt at value control. Dent Clin North Am. 1998;42(4):60712.

3- Anusavice KJ. Phillips' science of dental materials. 10th ed. Philadelphia: WB Saunders Company; 1996. p.598-600.

4- Bessing C, Wiktorsson A. Comparison of two different methods of polishing porcelain. Scand J Dent Res. 1983;91(6):482-7.

5- Camacho GB, Vinha D, Panzeri H, Nonaka T, Goncalves M. Surface roughness of a dental ceramic after polishing with different vehicles and diamond pastes. Braz Dent J. 2006;17(3):191-4.

6- Clelland NL, Agarwala V, Knobloch LA, Seghi RR. Wear of enamel opposing low-fusing and conventional ceramic restorative materials. J Prosthodont. 2001;10(1):8-15.

7- Craig RG, Powers JM, Wataha JC. Dental Materials: properties and manipulation. Saint Louis: Mosby; 2004. p.113.

8- Fuzzi M, Zaccheroni Z, Vallania G. Scanning electron microscopy and profilometer evaluation of glazed and polished dental porcelain. Int J Prosthodont. 1996;9(5):452-8.

9- Hulterstrom AK, Bergman M. Polishing systems for dental ceramics Acta Odontol Scand. 1993;51(4):229-34.

10- Jagger DC, Harrison A. An in-vitro investigation into the wear effects of unglazed, glazed, and polished porcelain on human enamel. J Prosthet Dent. 1994;72(3):320-3. 
11- Jefferies SR. The art and science of abrasive finishing and polishing in restorative dentistry. Dent Clin North Am. $1998 ; 42(4) ; 613-27$

12- Lawn BR, Pajares A, Zhang Y, Deng Y, Polack MA, Lloyd IK, et al. Materials design in the performance of all-ceramic crowns. Biomaterials. 2004;25(14):2885-92.

13- Lohbauer U, Krämer N, Petschelt A, Frankenberger R. Correlation of in vitro fatigue data and in vivo clinical performance of a glassceramic material. Dent Mater. 2008;24(1):39-44.

14- Lohbauer U, Müller FA, Petschelt A. Influence of surface roughness on mechanical strength of resin composite versus glass ceramic materials. Dent Mater 2008;24(1):250-6.

15- Martinez-Gomis J, Bizar J, Anglada JM, Samso J, Peraire M. Comparative evaluation of four finishing systems on one ceramic surface. Int J Prosthodont. 2003;16(1):74-7.

16- Paravina RD, Powers JM. Esthetic color training in dentistry. Saint Louis: Mosby; 2004. p.43-4.

17- Patterson CJ, McLundie AC, Stirrups DR, Taylor WG. Efficacy of a porcelain refinishing system in restoring surface finish after grinding with fine and extra fine diamond burs. J Prosthet Dent. $1992 ; 68(3): 402-6$.
18- Raimondo RL Jr, Richardson JT, Wiedner B. Polished versus autoglazed dental porcelain. J Prosthet Dent. 1990;64(5):553-7. 19- Sarac D, Sarac YS, Yüzbasioglu E, Bal S. The effects of porcelain polishing systems on the color and surface texture of feldspathic porcelain. J Prosthet Dent. 2006;96(2):122-8.

20- Schlissel ER, Newitter DA, Renner RR, Gwinnett AJ. An evaluation of postadjustment polishing techniques for porcelain denture teeth. J Prosthet Dent. 1980;43(3):258-65

21- Scurria MS, Powers JM. Surface roughness of two polished ceramic materials. J Prosthet Dent. 1994;71(2):174-7.

22- Tholt de Vasconcelos B, Miranda WG Jr, Prioli R, Oda M. Surface roughness in ceramics with different finishing techniques using atomic force microscope and profilometer. Oper Dent. 2006;31(4):442-9.

23- Whitehead SA, Shearer AC, Watts DC, Wilson NHF. Comparison of methods for measuring surface roughness of ceramic. J Oral Rehabil. 1995;22(6):421-7.

24- Wright MD, Masri R, Driscoll CF, Romberg E, Thompson GA, Runyan DA. Comparison of three systems for the polishing of an ultra-low-fusing dental porcelain J Prosthet Dent. 2004;92(5):48690. 